\title{
Sources, Formation and Socio-Historical Context of the Joseph Narrative: Re-Examined under the Documentary Hypothesis*
}

\author{
EMMANUEL KOJO ENNIN ANTWI (KWAME NKRUMAH UNIVERSITY OF \\ SCIENCE AND TEChNOlogy, KUMASI, GHANA)
}

\begin{abstract}
The historical-critical method has given birth to many approaches to the study of the Bible. As a consequence, many scholars have come up with solutions to some of the exegetical problems in the Judeo-Christian scriptures. One of the most popular proposed solutions to the problems in the Pentateuch is the Documentary Hypothesis. With time, the findings of the hypothesis have been challenged in reference to some texts in the Pentateuch. This paper seeks to re-examine the sources, formation and the socio-historical context of the Joseph narrative under the Documentary Hypothesis. It evaluates the Joseph narrative under the hypothesis in the light of its critique by later scholars. The essay argues that the narrative is composed of already-existing materials from the Ancient Near East, Egypt and the traditions from Israel to reflect some aspects of the history of Israel in retrospect. Weighing the sources according to the hypothesis as against the views of its critics, who accept the narrative as a unity, one discovers that some traces of source criticism are apparent in the views of the critics of the Documentary Hypothesis. They were solving similar problems within the narrative but from different perspectives.
\end{abstract}

KEYWORDS: Joseph narrative; Documentary Hypothesis; Source criticism; Yahwist source; Elohist source; Priestly source.

\section{A INTRODUCTION}

Chapters 37 to 50 of Genesis constitute the Joseph narrative. It contains not only a story about Joseph per se, but also a narrative about his father, brothers, and sons who make up the eponymous ancestors of the twelve tribes of Israel. The terms "Joseph narrative" and "Joseph story" are given to this entire block of narrative due to the fact that Joseph as protagonist features prominently in the narrative. This block of narrative which concludes the book of Genesis is very significant to the Pentateuch as the incidents narrated therein link the book

\footnotetext{
* Article submitted: 3/05/2016; final peer review: 3/06/2016; accepted: 4/07/2016. Emmanuel Kojo Ennin Antwi, "Sources, Formation and Socio-Historical Context of the Joseph Narrative: Re-Examined under the Documentary Hypothesis," Old Testament Essays 29/2 (2016): 259-276. doi: http://dx.doi.org/10.17159/2312$\underline{3621 / 2016 / \mathrm{v} 29 \mathrm{n} 2 \mathrm{a} 3}$
} 
of Genesis not only to the exodus event but also, for that matter, the episodes narrated in the entire Pentateuch. ${ }^{1}$ Like most Old Testament texts, written in a period very distant from our own, it is very difficult to know exactly the various processes, places and periods at which the traditions and materials were once composed and added in the course of its redaction. Moreover, it is very complicated to determine the author, the date and the social milieu of the Joseph narrative.

Scholars, in different periods, have taken up the task of analyzing the text in order to answer some of the questions raised in connection with the aforementioned problems. Nonetheless, as much as they try, they arrive at different conclusions. The Documentary Hypothesis throws light on some of the problems in the narrative, such as the duplications, inconsistencies, and nonuniformity and it is utilized to determine its authorship, sources, date, and social milieu. With the advent of the critics ${ }^{2}$ of the Documentary Hypothesis, the question arises as to whether or not the Hypothesis should be rejected with reference to the study of the Joseph narrative. Taking into consideration the views from the works of Redford, Donner, Westermann and Dietrich, who all admit that the narrative is a unity, I will explore the socio-historical context of the Joseph story-its origin, development, date of composition and social milieu - to see what light it can shed on the relevance of the Documentary Hypothesis for the Joseph narrative.

\section{B SOURCES AND SOCIAL MILIEU OF THE JOSEPH NARRATIVE WITHIN THE FRAMEWORK OF THE DOCUMENTARY HYPOTHESIS}

The propounding of the Documentary Hypothesis by Graf-Wellhausen brought a dramatic turn in the study of the Pentateuch in particular and the Old Testament in general. Scholars, like Speiser (1964), ${ }^{3}$ von Rad $(1972)^{4}$ and Ellis $(1976)^{5}$ who followed this hypothesis demonstrated the tendency of attributing all the writings of the Pentateuch to the four proposed sources or the schools of

1 Cf. James K. Hoffmeier, “Joseph,” NIDOTTE IV: 805.

2 Cf. Robert E. Longacre, Joseph: A Story of Divine Providence, A Text Theoretical and Textlinguistic Analysis of Genesis 37 and 39-48 (Winona Lake: Eisenbrauns, 1989), 4; Jean Louis Ska, Introduzione alla lettura del Pentateuco: Chiavi per l'interpretatione dei primi cinque libri della Bibbia (Bologna: Centro Editoriale Dehoniano, 2000), 150-161; Gary A. Rendsburg, The Redaction of Genesis (Winona Lake: Eisenbrauns, 1986), 102, 105-106.

3 Ephraim A. Speiser, Genesis: Introduction, Translation, and Notes (New York: Doubleday, 1964).

4 Gerhard von Rad, Genesis: A Commentary, OTL (Philadelphia: Westminster Press, 1972), 439-440. In reference to the Joseph narrative, he shares the view that it was a Novelle which was possibly incorporated by the Yahwist.

5 Peter F. Ellis, The Men and the Message of the Old Testament (Collegeville: Liturgical Press, 1976). 
Antwi, “Joseph-narrative and Documentary Hypothesis,” OTE 29/2 (2016): 259-276 261

writers; namely, the Yahwist (J), Elohist (E), Deuteronomist (D) and the Priestly (P). ${ }^{6}$

The book of Genesis is devoid of the Deuteronomist source-as the Deuteronomist source stands on its own as the book of Deuteronomy ${ }^{7}$-and consequently we could talk of only $\mathrm{J}$ E P sources for the book of Genesis. ${ }^{8}$ It follows logically that the Joseph narrative, being part of the book of Genesis, will testify to the presence of these three sources (JEP) from the point of view of the Documentary Hypothesis. ${ }^{9}$ Green affirms this by quoting Wellhausen in asserting that the main sources of the Joseph story are $\mathrm{J}$ and E. ${ }^{10}$ The combination of the two sources and the final editing were done by the priestly writers using other literary materials and connective elements. For instance, we find in Genesis 37:2 one of the connective elements, אִלְּה writers to link their materials. ${ }^{11}$

Speiser and Ellis outline the sources of the Joseph narrative also indicating those sources that have been combined. From their listing it is clear that most of the materials belong to $\mathrm{J}$ and E. ${ }^{12}$ Ellis presents the following as belonging to the J source in Genesis: ch.37:1-2a, 3-4, 12-13, 14b, 18b, 21, 23a, 25-27, 28b, 31a, 32b-33, 35; chs. 38-39; ch. 42:27-28, 38; ch. 43:1-13, 15-23a, 24-34; chs. 44-45; ch. 46:28-34; ch. 47:1-6b, 12-27a, 29-31; ch. 48:1-2, 8-22; chs. 49:1b-28a; ch. 50:1-11, 14. The E source consists of ch. 37:2b, 5-11, 14a, 15-18a, 19-20, 22, 23b-24, 28a, 28c-30, 31b-32a, 34, 36;chs. 40-42:1-37; ch. 43:14, 23b; ch. 45; ch. 46:28-34; ch. 47:1-6b, 12-27a, 29-31; ch. 48:1-2, 8-22; ch. 49:1b-28a; ch. 50:1-11, 14. The P source is made up of ch. 37:1-2a, ch. 41:46; ch. 45:5b-27; ch. 47:5.6a, 7-11, 27b-28; ch. 48:3-7; ch. 49:1-33;ch. $50: 12-13$. As it can be noted in the listing, some of the figures overlap and

6 W. Randolf Tate, Handbook for Biblical Interpretation: An Essential Guide to Methods, Terms, and Concepts (Grand Rapids: Baker Academic, 2012), 126, 182183. The Documentary Hypothesis "was developed by K. H. Graf and refined and popularized by Julius Wellhausen." Cf. Eugene H. Merrill, AnHistorical Survey of the Old Testament, $2^{\text {nd }}$ ed. (Grand Rapids: Baker Academic, 2008), 25-26. Jean Astruc is said to have originated the Documentary Hypothesis when he affirmed that Genesis was written by two people one using the name Elohim and the other Yahweh for God and these two materials were put together by Moses.

7 Bernhard W. Anderson, The Living World of the Old Testament (Harlow: Longman, 1988), 21.

8 Speiser, Genesis: Introduction, Translation, and Notes, xxii.

9 Cf. William H. Green, The Unity of the Book of Genesis, (New York: Charles Scribner's Sons, 1895), 433.

10 Green, The Unity of the Book of Genesis, 433; cf. Von Rad, Genesis: A Commentary, 348.

11 Cf. Anderson, The living World of the Old Testament, 464-465.

12 Cf. Ellis, The Men and the Message of the Old Testament, 63-65; Speiser, Genesis: Introduction, Translation, and Notes, 287-378. 
appear in different sources indicating that they are a combination of different sources. Speiser, in turn, differs from Ellis's listing in few instances. He does not indicate the combined sources either.

With regard to the socio-historical context, taking the Documentary Hypothesis as their point of departure, the earlier source critics construed the sources, the date for the composition of the Joseph story, and its social milieu. They proposed the following sources for Genesis, namely; J E P, with most sources being attributed to $\mathrm{J}$ and $\mathrm{E}$ while the hand of $\mathrm{P}$ is seen in the final redaction incorporating all the sources into the book of Genesis. Scholars were able to draw a link between the period in which these sources were composed and the social milieu that these sources of the Joseph narrative reflected. In that regard, the J source of the Joseph narrative could have been written around 950 BCE in the Southern Kingdom during the United Kingdom, the E source around $850 \mathrm{BCE}$ in the Northern Kingdom, whereas the final redaction was done by the Priestly writers around 550 BCE or later. ${ }^{13}$ Nonetheless, the fact that the narratives were composed in certain periods does not imply that their social milieu necessarily reflect these periods since most of the incidents took place before they were recorded.

Other scholars who saw the story of Joseph as part of the patriarchal narratives had the tendency of contextualizing the entire narrative, with regard to its social milieu attributing it to the period of the patriarchs. Green, for example, discusses some of the views put forward by Wellhausen and other scholars that the Joseph narrative was part of the patriarchal narrative, drawing on some parallels between them. He is of the view that the Joseph narrative is linked to the patriarchal narratives and that it shares in the same general pattern with them. ${ }^{14}$ Green sees the migration of Jacob's family as a means through which God preserves the posterity of Abraham as promised, thus admitting that the historicity of the narrative could be linked to what has in reality taken place in Egypt. In view of the fact that the patriarchs were said to have lived around the $2^{\text {nd }}$ millennium BCE, some scholars attributed most of the patriarchal practices and their setting to reflect this period. ${ }^{15}$ Hence, similar to the way they understood and analyzed the patriarchal narratives, they discovered possible historical parallels between the wider context of the Ancient Near East and the Joseph narrative.

\footnotetext{
13 Anderson, The living World of the Old Testament, 21-22.

14 Green asserts for instance that "the story of Joseph, complete as it is in itself, is but one link in a uniform and connected chain, and is of the same general pattern with those that precede it." Green, The Unity of the Book of Genesis, 431. Cf. Von Rad, Genesis: A Commentary, 347-348.

15 Cf. Joseph Blenkinsopp, The Pentateuch: An Introduction to the first Five Books of the Bible (New Haven: Yale University Press, 1992), 127-129; Anderson, The living World of the Old Testament, 45-46.
} 
Taking the Joseph story itself into consideration, and seeing most of the events taking place in Egypt, and the inherent possible identifiable Egyptian materials, ${ }^{16}$ a few scholars have come to the conclusion that the story might have originated from Egypt. A lot of parallels have been drawn between the narrative and the earlier Egyptian culture and history, for instance, associating Joseph's rise to power with the period of the Asiatic invaders, the Hyksos, around the $18^{\text {th }}$ and $17^{\text {th }}$ century BCE. ${ }^{17}$ The movement of Jacob's family is also likened to the movement of the mercenary group, the Hapiru (Habiru, Apiru) - from whose name the term "Hebrew" is assumed to have been derived-attested to in $2^{\text {nd }}$ millennium Mesopotamian and Egyptian documents. $^{18}$

\section{CRITIQUE OF THE DOCUMENTARY HYPOTHESIS WITH REGARD TO THE JOSEPH NARRATIVE}

The Documentary Hypothesis was only a proposition and thus amenable to change through criticism and challenges. ${ }^{19}$ It attracted criticism from various scholars, even to the extent that other minor sources were inferred on the basis of the main sources proposed by the hypothesis. ${ }^{20}$ The proposed sources for the Joseph narrative were not exempted from this critique. ${ }^{21}$ The sources, date, composition and social milieu of the Joseph narrative suggested by the source critics have thus been criticized on various grounds by the critics of the Documentary Hypothesis.

16 John Skinner, A Critical and Exegetical Commentary on Genesis, ICC (Edinburg: T\&T Clark, 1951), 442, 445. Some of the Egyptian materials found, are the temptation of Joseph by Potiphar in the Egyptian popular tale about two brothers and the allusion to Joseph as a magician. Cf. also William F. Albright, "The Old Testament, "IB 1: 252.

17 Lawrence Boadt, Reading the Old Testament: An Introduction (New York: Paulist Press, 1984), 153. Cf. Albright, IB 1:252-254; Sarna, Understanding Genesis, 224225. Sarna drew most of these parallels. One of them is the association of the settlement with the period of the Hyksos. Joseph allowed his family to settle in Goshen for two reasons: its accessibility to him and the royal palace, and the quality of the field for grazing livestock. The implication is that the capital of Egypt at the time might have been close to a good grazing field. The only possibility is Avaris. It fits into this description and as capital was founded in $1725 \mathrm{BCE}$ by the Hyksos. See also Gordon and Rendsburg, The Bible and the Ancient Near East, 63-4.

18 Cf. Anderson, The living World of the Old Testament, 39-40.

19 Anderson, The living World of the Old Testament, 21-2.

20 Cf. Blenkinsopp, The Pentateuch: An Introduction to the first Five Books of the Bible, 13-15; Iain Provan, V. Philips Long, and Temper Longman III., A Biblical History of Israel (London: Westminster John Knox Press, 2003), 25-31; R. Norman Whybray, Introduction to the Pentateuch (Grand Rapids: Eerdmans, 1995), 16.

21 Cf. Roy L. Heller, Narrative Structure and Discourse Constellations: An Analysis of Clause Function in Biblical Hebrew Prose, HSS LV (Winona Lake: Eisenbrauns, 2004), 33. 
The latter found the generalization of the proposed sources, author(s), date of composition and social milieu of the book of Genesis for all the narratives, and their subsequent extrapolation to the Joseph narrative extremely problematical and unsatisfactory. Studies of the development of biblical texts have revealed that most texts, if not all, underwent a redactional process in which other texts were later added in the course of their transmission. In some cases, older stories were retold to reflect new situations ${ }^{22}$ and in other circumstances some stories were expanded with new materials. In other words, the period in which a text was written may not necessarily point to the time when the incident that is narrated in actual fact took place. In addition, we are not certain when the book of Genesis itself assumed its present form, though many convincing conjectures have been made. ${ }^{23}$ Using these conjectures to ascertain the date and composition of the Joseph narrative might not be tenable and could be challenged with new insights in the course of time.

Furthermore, the Documentary Hypothesis was offered as a solution to the duplications, inconsistencies and the non-uniformity found in the Pentateuch. The use of sources with different tradition trajectories and different historical backgrounds accounted for the duplications and non-uniformity. But some exegetes have found the Joseph narrative to be a unit. These scholars identified the story of Joseph as a "romance," a "novella" or "historical fiction," forming a unity or, at least distinct and definite block of narrative. ${ }^{24}$ This view is deemed somewhat problematical, as it questions the historicity of the narrative. $^{25}$ It must be noted, nonetheless, that irrespective of its genre classification, as Dan Ben-Amos pointed out, its veracity cannot be doubted and the narrative enjoyed historical-religious validity in ancient Israel with regard to faith. ${ }^{26}$

Questions have been raised on the association of the social milieu of the Joseph narrative with that of the patriarchal narratives. Most later texts citing the patriarchs mention only Abraham, Isaac and Jacob, leaving out Joseph. The latter receives more prominence in the Jacob-Joseph narrative than his brothers. However, it is not Joseph but his two sons, together with the brothers of Joseph

\footnotetext{
22 Blenkinsopp, The Pentateuch: An Introduction to the first Five Books of the Bible, 125.

23 John J. Scullion, "The Narrative of Genesis," $A B D$ 2: 942: "It is not known who gave to posterity the final biblical text of Genesis or when this was done, though it can scarcely have been pre-exilic."

24 Cf. James K. Hoffmeier, Israel in Egypt: The Evidence for the Authenticity of the Exodus Tradition (New York: Oxford University Press, 1996), 77; Heller, Narrative Structure and Discourse Constellations, 33; Von Rad, Genesis: A Commentary, 439. Michael D. Coogan, The Old Testament: A Historical and Literary Introduction to the Hebrew Scriptures (Oxford: Oxford University Press, 2006), 75.

25 Cf. Hoffmeier, Joseph, 807.

26 Dan Ben-Amos, "Folklore in the Ancient Near East," ABD 2:825.
} 
who constitute later on the eponymous ancestors of the twelve tribes of Israel (Exodus $2: 24 ; 3: 6 ; 15: 4-5$ ). This aspect indicates that Joseph himself might not have been earlier on acknowledged as one of the patriarchs. ${ }^{27}$ If we look at the interconnectedness of the patriarchal narratives, we observe that the narrative of Abraham is intertwined with that of Isaac. When Abraham leaves the scene, the narrative of Isaac is connected to the story of Jacob in a way very similar to the way in which the stories of Jacob and Joseph are connected. In the JacobJoseph narrative, when Jacob leaves the scene Joseph is given more attention than his brothers. The patriarchs (Abraham, Isaac, and Jacob) were singled out from their siblings and given more prominence in the narratives. Since Joseph forms the link between the patriarchal narratives and the formation of Israel in the exodus tradition, one would expect him to be given recognition quite similar to that of the patriarchs. This is however not the case as evidenced in the mentioning of the patriarchs in other later texts. There are some motifs, theology and practices in the narrative which differ sharply from those of the patriarchal narratives. The God of the patriarchal narratives is seen to be more active than the one of the Joseph story in which the deity is seen working in the background. The Joseph narrative could therefore be seen in its own context separately from not only the patriarchal narratives but also from the general notions accepted for the date and composition of the book of Genesis.

Despite the criticisms put forward by some present-day scholars against the historicity of the Joseph narrative and its association with the patriarchal narratives, there are still biblical scholars adhering to a model in which the biblical text is equated with historical event, whereby the incidents described in the Joseph narrative that took place in Egypt are thought to have happened just as they are presented in the biblical text, turning the narrative into a true historical record. For instance, discussing the problem of the historicity and the Egyptian data in the narrative, Hoffmeier in the end concluded, agreeing with Kitchen, that the Egyptian elements in the narrative are a clear evidence of the historicity of the narrative and it might have been composed in the late Bronze Age, which is around the $13^{\text {th }}$ century BCE. ${ }^{28}$ However, the Joseph narrative might have been re-edited in the period of the monarchy. The Egyptian setting of the Joseph narrative has also attracted scholarly attention. The name of Joseph and the exact time when he reigned in Egypt are not found in the annals of Egypt. ${ }^{29}$ Accordingly, its association with the time of the foreign Hyksos, who ruled Egypt, remains questionable, though scholars affirm its possibility. ${ }^{30}$

27 Cf. Provan, Long, and Longman III,A Biblical History of Israel, 121.

28 Hoffmeier, Israel in Egypt, 98.

29 Coogan, The Old Testament: A Historical and Literary Introduction to the Hebrew Scriptures, 75.

30 Some affirm that the reign of the foreign Hyksos in Egypt might reflect the period of Joseph as a foreigner occupying a high governing position in Egypt. Cf. Coogan, The Old Testament: A Historical and Literary Introduction to the Hebrew Scriptures, 
In the wake of the above-mentioned critique, other biblical exegetes have come up with another model of studying the Joseph narrative. They are convinced that we need to study the narrative separately from the general methods of studying the book of Genesis and the Documentary Hypothesis. Failure to do so, they argue, may lead the scholar into a false generalization of the composition and the socio-historical context of the narrative. Donald Redford, Herbert Donner, Claus Westermann and Walter Dietrich are some of these scholars who go beyond the Documentary Hypothesis to study the narrative as a unity on its own context.

\section{Donald Redford (1970/1992)}

Redford points out that, in case the $\mathrm{J}$ and $\mathrm{E}$ sources are accepted as the main sources of the Joseph narrative, it will be difficult associating its setting with that of the patriarchal narratives. Redford puts forward some characteristics of the Joseph narrative which differentiate it from the patriarchal narratives. These are mostly in the fact that the patriarchal narratives are uneven unlike the Joseph story which exhibits a single rather than a composite authorship. ${ }^{31}$ The theology of the Joseph narrative is also quite different from that of the patriarchal narratives. The intensity of the cults and etiology are minimized in the Joseph narrative. Hebron, Shechem and Dothan, which play a significant role in the patriarchal narratives, are mentioned briefly. The Jewish exclusivism in the patriarchal narratives is also minimized in the Joseph story. For instance the Egyptians could mix with Joseph and his brothers. ${ }^{32}$

Redford analyses twenty-three factors which are used to support the ancient Egyptian influence on the narrative and argues that they reflect not only the practices of the ancient Egypt in the period around the $2^{\text {nd }}$ millennium BCE but also practices in the period of the middle of the $1^{\text {st }}$ millennium $\mathrm{BCE}{ }^{33}$ In other words, the Egyptian influence, when taken into consideration, reflects better the Saite period, which ran from around 664 BCE until 323 BCE, or a period later than the $2^{\text {nd }}$ millennium Egyptian period. He cites about fifty words and expressions which are also found in other exilic and post-exilic literature

75. Hendrik Jagersma, A History of Israel from Alexander the Great to Bar Kochba (London: SCM Press Ltd., 1994), 35-36; Merrill, An Historical Survey of the Old Testament, 95-96.

31 Donald B. Redford, A Study of the Biblical Story of Joseph: (Genesis 37-50). VTSuppl. XX (Leiden: Brill, 1970), 246.

32 In chapter $43: 32$, the narrator intrudes to explain why Joseph and his brothers were served with the meal separately from the Egyptians. The Jewish exclusivism is minimized in late literature and some believe that the narrative might have belonged to the later literature.

33 For the details on these 23 factors see Redford, A Study of the Biblical Story of Joseph, 187-243. 
and he proposes the possibility of the narrative having been composed somewhere around these two periods. ${ }^{34}$

Redford draws an analogy between ancient literature and the biblical text, namely that in a good number of these ancient writings, one can find some retrospective incidents which reflect a past event while the incidents recorded do not necessarily reflect the time in which they were being recorded. ${ }^{35} \mathrm{He}$ argues that, correspondingly, the story of Joseph does not appear in the historical and prophetic books due to the fact that the narrative might not have been known to their writers. This argument makes sense if the assigned date of the historical background is around 650-425 BCE, when the incidents of the Diaspora were a reality.

He also points out that there is an element of timelessness and placelessness in the story by arguing that the author frequently uses some terms denoting family relationship like "father," "younger brother" $(37: 10 ; 42: 15 ; 48: 19)$ and sometimes prefers titles to names. ${ }^{36}$ The timelessness and placelessness he identifies in the story could be explained in terms of historicity in that there is a difficulty in attributing a specific setting to the story.

Following from the above arguments, I would argue that Redford disagrees with the source critics who hold the view that the Joseph story is composed of the $\mathrm{J}$ and $\mathrm{E}$ sources, and that he proposes that the narrative is a combination of, on the one hand, an original Reuben version which might have been considered by the source critics as the Elohist source, and on the other hand, a later Judah expansion which might have also been considered by the source critics to be the Yahwist source. These two materials were later brought together and worked over by a redactor, with both versions having their origin in the period around 650-550 BCE. ${ }^{37}$ The only hand in connection with the sources constructed by the Documentary Hypothesis, which he sees throughout the book of Genesis, is that of the Priestly Writers. Redford proposes that the Joseph story was a novella created around the $7^{\text {th }}$ or $6^{\text {th }}$ century BCE supposedly at the end of the Judean monarchy or the exile, from a story which might have been in use in Egypt at the time the Pentateuch was being committed to writing. ${ }^{38}$

34 Redford, A Study of the Biblical Story of Joseph, 146-7. See Donald B. Redford, Egypt, Canaan and Israel in Ancient Times (Princeton N.J.: Princeton University Press, 1992), 425.

35 Redford, A Study of the Biblical Story of Joseph, 244.

36 Redford, Egypt, Canaan and Israel in Ancient Times, 423.

37 Redford, A Study of the Biblical Story of Joseph, 252-3.

38 Redford, Egypt, Canaan and Israel in Ancient Times, 429. 


\section{Herbert Donner (1976)}

Donner also accepts the unity of the story of Joseph and asserts that the criteria put forward by the source critics for the Pentateuch are lacking in the Joseph narrative. ${ }^{39}$ Thus, like Redford, he moves away from the traditional view that the entire narrative might have been the work of the proposed $\mathrm{J}$ and $\mathrm{E}$ writers and proposes that we need to look beyond the Documentary Hypothesis for a different source for the narrative.

He analyses some of the proposals from the source critics, for example the proposition that there was a jehovistischen Werkes $\left(\mathrm{R}^{\mathrm{JE}}\right)^{40}$ material from the $\mathrm{J}$ and E sources which concerns the movement of the clan of Jacob to Egypt. The $\mathrm{J}$ is said to have contained the movement of the clan to Egypt and the E, on the other hand, might have contained a story about Joseph which was later added to complete the story. This hypothesis goes further to indicate that the Joseph story might have had four fragments: (i) Genesis 41:50-52, the birth of Manasseh and Ephraim; (ii) Genesis 46:1ab-5a, the revelation to Jacob in Beersheba with regards to his journey; (iii) Genesis 48, the legitimation of Ephraim and Manasseh by Jacob; (iv) Genesis 50:23-25, the death of Joseph. ${ }^{41}$ However, Redford failed to indicate how these four fragments as proposed by the source critics accord well with the Joseph novella.

Donner proposes that the Joseph narrative might have originated from Jerusalem as a wisdom novella between the era of David and Solomon or possibly, shortly after their rule. ${ }^{42}$ The novella found its way into the Pentateuch in order to bridge the gap between Jacob's family and the exodus event. However, he admits that there is not enough evidence with regard to the redactional process of the Joseph narrative.

\section{Claus Westermann (1982/1986)}

Like Donner, Westermann accepts that the Joseph narrative exhibits a unity but with the exception of the presence of a lot of variations within the story itself. He rejects the view that the narrative might have been the work of the $J$ writers. The style and the nature of the $\mathrm{J}$ material in Genesis 12-36 differs completely from the content of the Joseph narrative attributed to $\mathrm{J}{ }^{43}$ In this vein, he proposes to consider a different author who might have not depended on oral tra-

39 Herbert Donner, Die literarische Gestalt der alttestamentlichen Josephsgeschichte in Sitzungsberichte der Heidelberger Akademie der Wissenschaften: Philosophischhistorische Klasse II (Heidelberg: Carl Winter: Universitätsverlag, 1976), 24.

40 Literally, it means Yahwistic works (material).

41 Donner, Die literarische Gestalt der alttestamentlichen Josephsgeschichte, 26-27. Cf. Anderson, The living World of the Old Testament, 46.

${ }_{42}$ Donner, Die literarische Gestalt der alttestamentlichen Josephsgeschichte, 24.

43 Claus Westermann, Genesis. 3 vols. Teilband Genesis 37-50, BK $1 \backslash 3$ (Neukirchen-Vluyn: Neukirchener, 1982), 16. 
$\overline{\text { ditions but could have put together different motifs from well-known narratives }}$ to attain his goal.

The author uses the Jacob narrative as his exposition and thus continuing the patriarchal narrative. ${ }^{44}$ The Joseph narrative is a family history interwoven with a narrative about a political history (Staatserzählung). They correspond to the two phases $f$ the history of Israel, namely the patriarchal period and the beginning of the monarchical period (Königszeit), trying to answer the basic question about the superiority of one brother over the other with regard to governance. ${ }^{45}$ He sees the wisdom motifs especially in chapters $40-41$, as having links with the royal courts and possibly might have reflected the early period of the Monarchy. ${ }^{46}$ He finds in the narrative two expansions: $39-41$ and $42-45$, the former in which we find some royal motifs where all the roles played are political, and the latter which reveals both a family and political dimension. ${ }^{47}$ Thus the roles which the characters played have some political undertones pointing to who is superior to the other.

The setting of the story in Egypt, whereby a supposed patriarch of Israel could live in Egypt in the courtyard of Pharaoh and rise to the position of a governor, could be meaningful and possible only in the period of Solomon, a time when Israel had good relationships with Egypt. It was within this epoch that we could talk of the possibility of the influence of Egyptian culture with regard to Israelite literature. ${ }^{48}$ For that reason Westermann suggests that the Egyptian elements found in the story are indicative of the Solomonic period. Some of these Egyptian motifs, such as the younger brother rising above his elderly siblings, he admits, also exist not only in other biblical texts, but also in a number of Ancient Near Eastern literature. ${ }^{49}$ Like Redford, Westermann proposes that the story could have originated from the Davidic-Solomonic period, around the $6^{\text {th }}-5^{\text {th }}$ century BCE.

\section{Walter Dietrich (1989)}

Like the aforementioned biblical scholars, Dietrich moves away from detecting different sources in the Joseph story. Instead, he argues for the Joseph narrative

44 Claus Westermann, Am Anfang. 1. Mose, Teil 2: Jakob und Esau, Die Josephserzählung (Neukirchen-Vluyn: Neukirchener-Vluyn, 1986), 370.

45 Westermann, Jakob und Esau, Die Josephserzählung,370, 372.

46 Westermann, Jakob und Esau, Die Josephserzählung, 370, 373.

47 Westermann, Genesis 37-50, 11.

48 Westermann, Jakob und Esau, Die Josephserzählung, 370, 373.

49 Westermann, Genesis 37-50, 17. 
being an independent composition used to serve as a bridge between the patriarchal and the exodus narratives. ${ }^{50}$

Dietrich sees the Joseph story not only as a family history but also as a history of a tribe or a clan, with social and political dimensions. For example, the names of the brothers represent the forefathers of Israel, and Joseph indicates Northern Israel over-against Judah in the south. ${ }^{51}$ The story seems to portray the political stance of the author to the reader, namely favouring the political agenda of the tribes of the younger brothers, Joseph and Benjamin. These two characters get the upper hand over two of their older brothers, Judah and Reuben, the latter nonetheless by birthright put into a position of supremacy over the younger siblings.

With regard to the sources for the narrative, Dietrich proposes that the author might have known what he calls the Davids-Geschichtsschreibung ${ }^{52}$ which is apparently used in the composition. ${ }^{53}$ Dietrich situates the story within the period of the division of the Kingdom after the death of Solomon, around the time of Jeroboam, possibly relating his flight to Egypt, thus suggesting the possibility of a Hebrew presence in Egypt. ${ }^{54}$ He substantiates this view by constructing good relationships between Egypt and Jeroboam's Israel, the Northern Kingdom, over against Rehoboam of Judah in the Southern Kingdom. The Joseph narrative was perhaps composed in an attempt to legitimize the reign of Jeroboam in the North as the clan of Joseph.

\section{Evaluation of the Arguments and its Implications}

Deducing from the views of Redford, Donner, Dietrich and Westermann, one can argue that the Joseph story formed a narrative unit block, independent of the sources of the Documentary Hypothesis. Working through their arguments one cannot ignore the possibility that the narrative is composed from different already-existing narrative motifs and materials. It might have been composed within the period of the monarchy, even originating from the royal court in Jerusalem itself (Donner, Dietrich and Westermann) or originating within that period, but completed later on and inserted into the book of Genesis by the priestly redactor (Redford). Though their assumptions are tenable, they do not distinctively and fully answer all the problems raised about the existence of the narrative before the advent of the Documentary Hypothesis. Some questions still linger on, for example, how do we answer the complication on the selling

50 Walter Dietrich, Die Josephserzählung als Novelle und Geschichtsschreibung: Zugleich ein Beitrag zur Pentateuchfrage. Biblisch-theologische Studien XIV (Neukirchen-Vluyn: Neukirchener, 1989), 10-12.

51 Dietrich, Die Josephserzählung als Novelle und Geschichtsschreibung, 14-15.

52 I will render that as Historiography of David.

53 Dietrich, Die Josephserzählung als Novelle und Geschichtsschreibung, 73.

54 Dietrich, Die Josephserzählung als Novelle und Geschichtsschreibung, 62-63. 
and the reselling of Joseph in Egypt in Genesis 37 in the light of the debate? Is the story of Judah in Genesis 38 part of the Joseph narrative? ${ }^{55}$ Their arguments can be evaluated in the light of other scholarly propositions.

Concerning the origin and sources of the narrative, Coats and Humphreys accept the view that the novella might have come from the Solomonic court, and in one way or another, they agree with Westermann and Donner. ${ }^{56}$ The narrative is perceived to exhibit the literary style of the Solomonic era, which becomes evidence of the possibility of originating from that period.

Other biblical scholars who have made a study of the history of Israel propose that the social milieu be seen as part of a period when Egypt had good contact with Israel-an idea quite similar to that of Westermann. Skinner, for instance, holds the view that, either the Egyptian materials might have been put together in Egypt and adopted for an Israelite hero Joseph, possibly during the Egyptian domination or it might have been imported later because of the Egyptian influence at the court of Jeroboam I. ${ }^{57}$ Skinner thus agrees with Westermann on the element of Egyptian borrowing, however, he disagrees with him regarding the identity of the king (Solomon) under whose regime the borrowing might have been possible and meaningful. Instead, he agrees with Dietrich on the possibility of Egyptian influence under the reign of Jeroboam I.

The presence of the Egyptian material does not necessarily imply that the narrative originated solely from Egypt. The Joseph narrative is a didactic wisdom narrative with elements of wisdom literature, of which one can trace a definite influence from Egypt. ${ }^{58}$ Humphreys admits that the traces of some of these elements which usually have been attributed to the Egyptian materials are also prevalent in other Ancient Near East cultures. ${ }^{59}$ For instance, some of the motifs and the materials in the narrative are found in wisdom circles and traditions. These wisdom motifs have parallels in other books and stories such as the stories of Daniel and Mordecai, all of which are said to have been written during the post-exilic period. It has also been proposed that the cognate paral-

55 Heller, Narrative Structure and Discourse Constellations, 39.

56 George W. Coats, "Joseph: Son of Jacob," $A B D$ 3:980. Coats proposes that the novella might have been composed in the Solomonic court and era or "some period shortly after that time when the patronage of the king could have supported such artistic composition. That time roughly the $10^{\text {th }}$ Century B. C. would correspond to the period traditionally identified as the time of the Yahwist production of the whole narrative tradition."

57 Skinner, "A Critical and Exegetical Commentary on Genesis," 442.

58 Scullion, "The Narrative of Genesis," $A B D$ 2:954; Von Rad, "Genesis: A Commentary," 435-438.

59 Humphreys, Joseph and his Family: A Literary Study, 159. Cf. also Skinner, "A Critical and Exegetical Commentary on Genesis," 459. Cf. Merrill, An Historical Survey of the Old Testament, 96. 
lels with the Ancient Near Eastern texts support the theory of the presence of an oral narrative in Israel that was "continuous with other near eastern oral narratives," thus giving credence to the possibility of the ancient authors being exposed to Mesopotamian, Canaanite, or Egyptian literary texts. ${ }^{60}$ In this case, it will be fair to admit that the entire narrative could have been an amalgam of Ancient Near Eastern traditions and motifs to suit its present place and context in the Pentateuch.

Ronald Hendel regards the roles played by the characters in the narrative of significant importance for the interpretation of the text. If the Joseph narrative is thought to reflect a time when Manasseh and Ephraim were said to be dominant, then the story could have been written in the era of the tribal league of Israel when Ephraim and Manasseh were the most populous tribes and had, apparently, a dominant status. All things being equal, if this view is accepted, the narrative could not have been written earlier than the early monarchy. ${ }^{61}$ Hendel finds the role of Reuben and Judah in the text indicative of its social milieu. The role of Reuben reflects a period when the tribe of Reuben was an important tribe and that of Judah, on the other hand, reflects a time after the rise of David when Judah became a dominant tribe. From the discussion of Hendel, it seems that the narrative does not reflect only one specific period. The implication is that there were different traditions which were composed at different times and eventually put together by a redactor or a skillful writer who had information relating to these periods and composed a narrative to reflect them.

The interest in the Northern Kingdom in some sections of the narrative made some scholars think that the story is biased towards the Northern Kingdom. This bias becomes the basis for scholars to see the possible influence of the Elohist on the narrative. ${ }^{62}$ The tribes of Manasseh and Ephraim in the north descended from Joseph who in the narrative is raised above his brothers. From other Deuteronomistic texts and prophetic literature, such as Josh, 18:11; Judg 1:22; 1Kgs 11:28, Ezek 37:19 and Zech 10:6, it seems clear that Joseph is "one of the eponymic 'fathers' of the twelve tribes of Israel," symbolizing "the Northern Kingdom, the nation of Israel in contrast to the Southern Kingdom, the nation of Judah." ${ }^{, 63}$ The tribe of Joseph might have been divided into the tribes of Manasseh and Ephraim, when Levi functioned no more as a secular tribe, in order to make up for the number "twelve" - a standard and significant structure in the political organization of Israel. ${ }^{64}$ This division appears in the narrative concerning the Joseph tradition in Gen 48:1-12, and in 13-20. ${ }^{65}$ The

60 Hendel, "Book of Genesis," $A B D$ 2: 937-939.

61 Hendel, "Book of Genesis," ABD 2: 937.

62 Cf. Coogan, The Old Testament: A Historical and Literary Introduction to the Hebrew Scriptures, 75.

63 Coats, "Joseph: Son of Jacob," ABD 3:976-977.

64 Coats, "Joseph: Son of Jacob," $A B D$ 3:976.

65 Coats, "Joseph: Son of Jacob," $A B D$ 3:977. 
narrator skillfully weaves the plot of the narrative to reflect the political situation at the time in order to attain his goal. The Northern Kingdom, which is symbolized by the tribes of Joseph-Ephraim and Manasseh-is given prominence and supremacy over the other southern tribes. The elder brothers who were to be superior by birthright are rather not raised above Joseph in the narrative. By so doing, the narrator answers the question why the younger eponymic father assumed superiority over his senior brothers.

\section{CONCLUSION}

From the ongoing discussion, it is quite clear that the origin, social milieu, authorship and composition of the Joseph narrative are not precise and for that reason it has been difficult to embark on a study of the socio-historical context of the text diachronically. Though the views of the source critics have been criticised and new insights evolved, most of these later scholars have not arrived at the author and the period of the composition of the narrative with precision. Nevertheless, some of the views of the source critics are apparent in the views of the later and contemporary scholars. For instance, the Documentary Hypothesis put forward two sources for the Joseph narrative, the $J$ and the E sources and the $\mathrm{P}$ as its redactor. Redford on the other hand identified a Reuben version and the Judah expansion which might have been considered by the source critics as the E and J sources respectively. While the sources answer the question of duplications and inconsistencies in the narrative, the critics of the Documentary Hypothesis find the expansions as the cause. Source critics and critics of the Documentary Hypothesis alike were all trying to solve the problems within the narrative but from different angles.

Even if we cannot attribute the narrative precisely to any of the proposed sources of the Pentateuch, there are still some characteristics which are akin to them. The Joseph narrative itself, through the synchronic analysis, reveals that most of the scenes took place in Egypt and its social milieu and historical context reflect a period no other than that of the patriarchal period. The narrative itself points to a period which might have implied the possibility of Egyptian borrowing $^{66}$ with the author possibly having some of the parallel traditions and tales before him. It is possible that the incidents taking place in Egypt do not necessarily imply that they took place historically in Egypt as others claim. Nevertheless, the historicity of some members of the tribes of Israel also not being in Egypt has not been proven adequately. ${ }^{67}$ If we accept the fact that the story was a novella and fiction as the critics of the Documentary Hypothesis claim, then it seems that the author intended writing not just an ordinary fiction

66 Cf. Gordon and Rendsburg. The Bible and the Ancient Near East, 135-137; Lee W. Humphreys, Joseph and his Family: A Literary Study (South Carolina: University of South Carolina Press, 1988), 158.

67 Daniel Hillel, The Natural History of the Bible: An Environmental Exploration of the Hebrew Scriptures (New York: Columbia University Press, 2006), 102. 
but a theologico-historical fiction, using the materials available to him. Thus he created a fiction out of the available materials he had in order to bring home his theological message. We need therefore to consider the story not just as an ordinary romance, fiction or novella, but as a historical fiction which was composed by the author to reflect a period in the history and the political life of Israel. $^{68}$

Despite the fact that we cannot accurately put the narrative in the same context as that of the patriarchal narratives, it seems evident that the author of the narrative and the redactors of Genesis had the intention of using it to bridge the gap between the patriarchal narrative and the exodus event. ${ }^{69}$ In his exposition of the Joseph narrative, the author used Jacob who is the last of the patriarchs. He then developed the plot around Joseph who is presented as the son of Jacob to explain how Israel got to Egypt before the exodus event. The author might have been motivated by the practice in the Ancient Near East, whereby important families traced their roots by writing stories that depicted their importance among their neighbours. ${ }^{70}$ In order to achieve his motive, he might have used the practices and motifs of his earlier ancient period, to reflect the period in retrospect. He might have found a tradition of an ancestor of Israel being in Egypt in their oral literature and wove the narrative with all the materials available to him concerning Egypt and the Ancient Near East. In short, a later skillful author ${ }^{71}$ having a gamut of already-existing materials stemming from Egypt, Ancient Near East and traditions from Israel might have composed the Joseph narrative to reflect earlier period. The priestly writers were responsible for its insertion into the book of Genesis.

\section{BIBLIOGRAPHY}

Albright, William F. “The Old Testament World.” Pages 233-271 in The Interpreter's Bible, vol. I. Edited by George A. Buttrick. New York: Abingdon Press, 1952.

Anderson, Bernhard W. The living World of the Old Testament.Harlow: Longman, 1988.

68 Cf. Anderson, The living World of the Old Testament, 46. "Nevertheless, the Joseph is not a pure fiction; it is a historical novel which belongs within the setting of the second millennium B. C. E."

69 Cf. Coats, "Joseph: Son of Jacob," $A B D$ 3:979.

70 Redford, A Study of the Biblical Story of Joseph, 5. It was a common practice in the Ancient Near East in the first millennium BCE for families of social standing to take interest in their distant ancestry.

71 Although "author" is used in this piece it must be understood in the context of a multiple authorship. We cannot attribute the narrative to a single authorship at a point in time. Different materials might have been composed out of which a redactor composed his story. This implies different persons worked on the narrative at different periods until it found its way into the book of Genesis. Cf. Jean Louis Ska, Introduzione alla lettura del Pentateuco: Chiavi per l'interpretatione dei primi cinque libri della Bibbia, 82. 
Antwi, “Joseph-narrative and Documentary Hypothesis," OTE 29/2 (2016): 259-276 275

Ben-Amos, Dan. "Folklore in the Ancient Near East." Pages 818-828 in The Anchor Bible Dictionary, vol. 2. Edited by David Noel Freedman, New York: Doubleday, 1992.

Blenkinsopp, Joseph. The Pentateuch: An Introduction to the first Five Books of the Bible. New Haven: Yale University Press, 1992.

Boadt, Lawrence. Reading the Old Testament: An Introduction. New York: Paulist Press, 1984.

Coats, George W. "Joseph: Son of Jacob." Pages 976-981 in The Anchor Bible Dictionary, vol. 3. Edited by David Noel Freedman, New York: Doubleday, 1992.

Coogan, Michael D. The Old Testament: A Historical and Literary Introduction to the Hebrew Scriptures. Oxford: Oxford University Press, 2006.

Dietrich, Walter. Die Josephserzählung als Novelle und Geschichtsschreibung: Zugleich ein Beitrag zur Pentateuchfrage. Biblisch-theologische Studien XIV. Neukirchen-Vluyn: Neukirchener, 1989.

Donner, Herbert. Die literarische Gestalt der alttestamentlichen Josephsgeschichte in Sitzungsberichte der Heidelberger Akademie der Wissenschaften: Philosophisch-historische Klasse II. Heidelberg: Carl Winter: Universitätsverlag, 1976.

Ellis, Peter F. The Men and the Message of the Old Testament. Collegeville: Liturgical Press, 1976.

Gordon, Cyrus H. and Gary A. Rendsburg. The Bible and the Ancient Near East. New York: W. W. Norton and Company, 1997.

Green, Barbara. "Joseph, Josephites." Pages 396-400 in The New Interpreter's Dictionary of the Bible, vol. III.Edited by Katharine Doob Sakenfeld. Nashville: Abingdon Press, 2008.

Green, William Henry. The Unity of the Book of Genesis. New York: Charles Scribner's Sons, 1895.

Heller, Roy L. Narrative Structure and Discourse Constellations: An Analysis of Clause Function in Biblical Hebrew Prose. Harvard Semitic Studies LV. Winona Lake: Eisenbrauns, 2004.

Hendel, Ronald S. "Book of Genesis," Pages 933-941 in The Anchor Bible Dictionary, vol. 2. Edited by David Noel Freedman. New York: Doubleday, 1992.

Hillel, Daniel. The Natural History of the Bible: An Environmental Exploration of the Hebrew Scriptures. New York: Columbia University Press, 2006.

Hoffmeier, James K. Israel in Egypt: The Evidence for the Authenticity of the Exodus Tradition. New York: Oxford University Press, 1996.

"Joseph." Pages 805-808 in New International Dictionary of Old Testament Theology and Exegesis, vol. IV. Edited by Willem A. VanGemeren. Grand Rapids: Zondervan, 1997.

Humphreys, Lee W. Joseph and his Family: A Literary Study. South Carolina: University of South Carolina Press, 1988.

Jagersma, Hendrik. A History of Israel to Bar Kochba. London: SCM Press Ltd., 1994.

Longacre Robert E. Joseph: A Story of Divine Providence, A Text Theoretical and Textlinguistic Analysis of Genesis 37 and 39-48. Winona Lake: Eisenbrauns, 1989. 
276 Antwi, “Joseph-narrative and Documentary Hypothesis," OTE 29/2 (2016): 259-276

Merrill, Eugene H. An Historical Survey of the Old Testament. 2nd Edition. Grand Rapids: Baker Academic, 2008.

Provan, Iain, V Philips Long, and Tremper Longman III. A Biblical History of Israel. London: Westminster John Knox Press, 2003.

Redford, B. Donald. A Study of the Biblical Story of Joseph: (Genesis 37-50).Vetus Testamentum Supplementum XX. Leiden: Brill, 1970. . Egypt, Canaan and Israel in Ancient Times. Princeton: Princeton University Press, 1992.

Rendsburg, Gary A. The Redaction of Genesis. Winona Lake: Eisenbrauns, 1986.

Sarna, Nahum M. Understanding Genesis: The World of the Bible in the light of History. New York: Shocken Books, 1966.

Scullion, John J. "The Narrative of Genesis." Pages 941-962 in Anchor Bible Dictionary, vol. 2. Edited by David Noel Freedman. New York: Doubleday, 1992.

Ska, Jean Louis. Introduzione alla lettura del Pentateuco: Chiavi per l'interpretatione dei primi cinque libri della Bibbia. Bologna: Centro Editoriale Dehoniano, 2000.

Skinner, John. A Critical and Exegetical Commentary on Genesis. International Critical Commentary. Edinburg: T\&T Clark, 1951.

Speiser, Ephraim A. Genesis: Introduction, Translation, and Notes, New York: Doubleday, 1964.

Tate, W. Randolph. Handbook for Biblical Interpretation: An Essential Guide to Methods, Terms, and Concepts. Grand Rapids: Baker Academic, 2012.

VanGemeren, Willem A. New International Dictionary of Old Testament Theology and Exegesis. 5 Vols. Grand Rapids: Zondervan, 1997.

Von Rad, Gerhard. Genesis: A Commentary, OTL. Philadelphia: Westminster Press, 1972.

Westermann, Claus. Am Anfang. 1. Mose, Teil 2: Jakob und Esau, Die Josephserzählung. Neukirchen-Vluyn: Neukirchener-Vluyn, 1986.

. Genesis. 3 vols. Teilband Genesis 37-50: Biblische Kommentar 1/3. Neukirchen-Vluyn: Neukirchener, 1982.

Whybray, R. Norman. Introduction to the Pentateuch. Grand Rapids: Eerdmans, 1995.

Rev. Dr. Emmanuel Kojo Ennin Antwi is a lecturer in the Department of Religious Studies at the Kwame Nkrumah University of Science and Technology, Kumasi, Ghana.Email:kojoantwi999@yahoo.de. 